\title{
Effect of Oxygen Content and Temperature On Stabilization of Arsenic in Copper Smelting System
}

\section{Shenghang Xu ( $\square$ shenghangxu@zjut.edu.cn)}

Zhejiang University of Technology

Bin $\mathrm{Hu}$

Zhejiang University of Technology

Huibin Zhang

Zhejiang University of Technology

\section{Min Wu}

Zhejiang University of Technology

\section{Yanan Wang}

Zhejiang University of Technology

\section{Yuzheng He}

Zhejiang University of Technology

\section{Huazhen Cao}

Zhejiang University of Technology

\section{Jun Zhou}

Tongling Nonferrous Metals Group Co.Ltd

\section{Guoqu Zheng}

Zhejiang University of Technology

\section{Research Article}

Keywords: Flash smelting system, Solidification/stabilization, Arsenic, Toxicity characteristic leaching procedure, Fayalite

Posted Date: February 9th, 2021

DOI: https://doi.org/10.21203/rs.3.rs-166415/v1

License: (c) (1) This work is licensed under a Creative Commons Attribution 4.0 International License. Read Full License 


\section{Abstract}

Arsenic-bearing wastes from copper smelting system are usually disposed by trapping them in slag tailing. However, arsenic in slag tailing is not that stable, which can infiltrate into the groundwater, threatening the environment and human health. The solidification/stabilization (S/S) of arsenic is the only way to deal with arsenic contamination. The flash smelting method shows relatively high $\mathrm{S} / \mathrm{S}$ ability of arsenic, but the process and mechanism remain unclear. In this paper, we aim at revealing the effect of atmosphere on the $\mathrm{S} / \mathrm{S}$ process of arsenic owing to the different content of oxygen in reaction shaft and sedimentation tank in copper smelting system. Calcium arsenate, $\mathrm{SiO}_{2}, \mathrm{Fe}_{2} \mathrm{O}_{3}$ and iron powders were sintered at different temperature in air and argon to simulate the $\mathrm{S} / \mathrm{S}$ reaction. The results show that the sintering product is $\mathrm{Fe}-\mathrm{Si}$ oxide in air and fayalite in argon, and the fayalite possesses better capacity to solidify arsenic than that of Fe-Si oxide. The toxicity characteristic leaching procedure (TCLP) results reveal that the leached concentration of arsenic from fayalite fabricated at $1200{ }^{\circ} \mathrm{C}$ is only $2.916 \mathrm{mg} \mathrm{L}^{-1}$, which satisfies the identification standard for hazardous substances in China. Furthermore, the theoretical calculation reveals that $\mathrm{AsO}_{4}$ and $\mathrm{SiO}_{4}$ tetrahedrons can be connected by $\mathrm{O}$ atoms when sintered in argon, and the $\mathrm{Si}-\mathrm{O}-\mathrm{As}$ covalent bond can evidently inhibit the release of As atom from fayalite. This work can not only clarify the $\mathrm{S} / \mathrm{S}$ mechanism of arsenic in flash smelting process, but also provide theoretical guidances to dispose arsenic-bearing waste harmlessly.

\section{Introduction}

Owing to the excellent ductility, thermal conductivity and electrical conductivity, copper and its alloys have been widely utilized in various fields, such as wires, cables, vacuum devices and high strength bearings, etc. The copper smelting industry has been rapidly developed in recent decades, and the annual output of copper in China has been more than 7 million tons (Yang et al. 2014). In general, the copper mineral in nature always exists as sulfide associated with arsenic element. During smelting process, arsenic element can be released, which is harmful to the environment and human health. Statistically, the content of As in the copper mineral is as high as $0.2 \mathrm{wt} . \%$, that is, the arsenic element brought into the environment through copper smelting system is up to 56000 tons every year in China. However, the capacity of arsenic containing products is rather limited, leading to the predicament that digesting all the arsenic-bearing waste is by no means a low-hanging fruit. Therefore, it is of great significance to seek an effective and safe method to dispose arsenic-bearing waste.

In order to reduce the toxicity of arsenic, solidification/stabilization (S/S) technology is always applied to dispose arsenic-bearing waste by restricting the mobility of As atoms. Several methods have been proposed to reduce arsenic contamination, such as cement solidification (Kundu and Gupta 2008; Yin et al. 2019; Yoon et al. 2010), geopolymer solidification (Shi et al. 2017; Xu et al. 2006) and vitrification solidification (Shi et al. 2015; Zhao et al. 2015; Zhao et al. 2016). As for the cement solidification method, arsenic atoms can be immobilized by three ways: Firstly, arsenic-bearing wastes can be enwrapped by cement (Liu et al. 2018); Secondly, arsenic can react with cement and form insoluble calcium-arsenic compounds (Vandecasteele et al. 2002), such as $\mathrm{Ca}_{3}\left(\mathrm{AsO}_{4}\right)_{2}$ and $\mathrm{CaHAsO}_{3}$; Thirdly, arsenic can be absorbed onto the surface of calcium silicate hydrate (C-S-H) (Li et al. 2018). However, cement is not stable and arsenic-bearing wastes can be 
exposed again after damaging the cement layer. Importantly, calcium-arsenic compounds as well as absorbed arsenic can gradually dissolve into acid solution and release As element into the environment. Therefore, the solidified arsenic can be easily escaped and contaminate water source. As for the geopolymer solidification, three-dimensional network of inorganic polymer (Jaarsveld et al. 1997; Jaarsveld et al. 1999) can effectively solidify arsenic by chemical and physical absorption. Luo et al. (Luo et al. 2015) have found that the geopolymer material can transform amorphous $\mathrm{As}(\mathbb{\nabla})$ into $\mathrm{As}(\mathbb{\nabla})$ in the arsenic calcium slag inspired

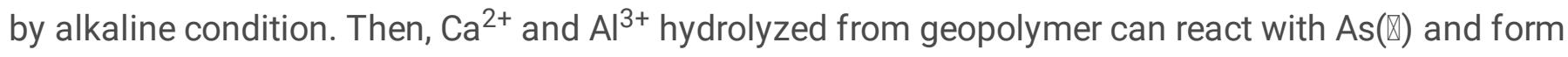
insoluble salts with Al-As-O and Ca-As-O covalent bond, leading to the immobilization of As element. However, the arsenic-bearing salts fabricated by geopolymer solidification can not guarantee long-term stability (Pantuzzo and Ciminelli 2010), especially in acid solution, and arsenic element can be released from the solidified products gradually (Sullivan et al. 2010). It is well accepted that $\mathrm{SiO}_{4}$ tetrahedron is relatively stable, and $\mathrm{AsO}_{4}$ tetrahedron can take place of $\mathrm{SiO}_{4}$ tetrahedron during the vitrification solidification process. Zhao et al. (Zhao et al. 2017) have melted $\mathrm{SiO}_{2}-\mathrm{Fe}_{2} \mathrm{O}_{3}-\mathrm{B}_{2} \mathrm{O}_{3}$ glass with sodium arsenate at $1200^{\circ} \mathrm{C}$, and found that the formed Si-O-As and $\mathrm{Fe}-\mathrm{O}-\mathrm{Si} / \mathrm{As}$ bonds could hinder the escape of As atoms from glass. Furthermore, the glass phase shows better stability than cements and insoluble salts, indicating that the vitrification solidification method is a potentially innocuous management to dispose arsenic-bearing wastes.

However, extra S/S process may bring out a severe financial burden for smelting enterprises, especially for the high capacity of arsenic-bearing wastes. Actually, flash smelting process shows an evidently selfsolidification behavior (Lv and Zhang 2018; Zhang et al. 2019; Zheng and Lin 2015), exhibited by the high content of arsenosilicate glass in the smelting slag. It is a wise way to solidified arsenic-bearing wastes during the flash smelting process. Previous studies (Zhang et al. 2020) have shown that the arsenic exists as arsenosilicate, which is a stable arsenic-bearing phase obtained by the vitrification of silicate at high temperature. During the flash smelting process, arsenic-bearing compounds and glass phases are apt to be vitrified, and therefore arsenic atoms can be immobilized in the glass phase, achieving the innocuous treatment of As. However, owing to the short smelting time, the exact procedures and mechanisms of selfsolidification of As element during the flash smelting process remain unknown, especially for where the arsenic-bearing glass phase formed? The differences of temperature and oxygen content are vast between reaction tower and the sedimentation tank in the copper smelting system. Therefore, the effect of smelting parameters, such as temperature and content of oxygen, on the formation of arsenic-bearing glass phase is rather significant to guide the self-solidification of As, yet corresponding research is scarce.

In order to clarify the mechanism of arsenic S/S in copper smelting process, in this paper, we simulated the flash smelting process and studied the effect of temperature and oxygen content on the stabilization of As element. The microstructural evolution of simulated slag and the stabilized bonding of As elements was also studied in detail. This work not only offers an appropriate parameter for flash smelting process to solidify arsenic, but also provides an effective strategy for realizing the harmless treatment of arsenic-bearing wastes.

\section{Experimental}

\subsection{Flash smelting slag}


The flash smelting copper slag in this work is provided by Tong Ling Nonferrous Metals, and the microstructure is shown in Fig. 1 . It can be seen that the surface of slag is covered by flaky $\mathrm{Fe}_{3} \mathrm{O}_{4}$, and the interior of slag is mainly composed of fayalite $\left(\mathrm{Fe}_{2} \mathrm{SiO}_{4}\right)$ and magnetite $\left(\mathrm{Fe}_{3} \mathrm{O}_{4}\right)$. The main chemical composition of the slag is measured by X-ray fluorescence (XRF) and the result is shown in Table 1. The content of arsenic element in the slag is $0.25 \mathrm{wt} . \%$ while that of Fe and Si reach up to $34.31 \mathrm{wt} . \%$ and 16.24 wt.\%, respectively.

Table. 1 The main chemical composition of flash smelting copper slag

\begin{tabular}{|lllllllllllll|}
\hline Element & $\mathrm{As}$ & $\mathrm{Fe}$ & $\mathrm{Si}$ & $\mathrm{Al}$ & $\mathrm{Mg}$ & $\mathrm{Ca}$ & $\mathrm{S}$ & $\mathrm{Cu}$ & $\mathrm{K}$ & $\mathrm{Zn}$ & $\mathrm{Pb}$ & 0 \\
\hline Wt.\% & 0.25 & 34.31 & 16.24 & 2.93 & 1.71 & 1.39 & 0.31 & 0.22 & 0.93 & 0.79 & 0.17 & 40.75 \\
\hline
\end{tabular}

Fig. 2 shows the XRD spectrum of the arsenic-bearing slag. It can be seen that the main phases in the slag are fayalite $\left(\mathrm{Fe}_{2} \mathrm{SiO}_{4}\right)$ and magnetite $\left(\mathrm{Fe}_{3} \mathrm{O}_{4}\right)$. The characteristic peak of silica phase $\left(\mathrm{SiO}_{2}\right)$ can also be detected around $2 \theta=23^{\circ}$. The amorphous glass phase is rather abundant in the slag. However, the diffraction peak of arsenic compound can not be found in XRD spectrum because of the limited arsenic content, as indicated by Table. 1 .

\subsection{Selectively sequential extraction procedures}

According to the different solubility of arsenic-bearing substances in various solutions, the selectively sequential extraction (SSE) procedures (Drahota et al. 2014; Tessier et al. 1979; Zhang et al. 2020) were used to identify the structure and the content of arsenic-bearing substances. The smelting slag is milled for $4 \mathrm{~h}$ with a milling speed of $250 \mathrm{rpm}$ and a ball-to-powder mass ratio of 10:1. Then, the slag powder is selected by a 200 mesh sieve and dried at $105^{\circ} \mathrm{C}$ for $1 \mathrm{~h}$. The SSE procedures are conducted as follows: Firstly, the slag powder is leached by boiling water to remove the water-soluble arsenate and arsenic oxide. Then, $0.5 \%$ citric acid solution $\left(\mathrm{C}_{6} \mathrm{H}_{8} \mathrm{O}_{7}\right)$ and $3 \mathrm{~mol} \mathrm{~L}^{-1} \mathrm{HCl}$ are utilized to separate soluble crystalline arsenate and insoluble arsenate (ferric arsenate and ferrous arsenate), respectively. Next, $2 \% \mathrm{NaOH}$ is applied to leach arsenic sulfide while acetic acid $\left(50 \mathrm{ml} \mathrm{HA}+50 \mathrm{ml} \mathrm{H}\right.$ O) solution is utilized to extract arsenopyrite. Finally, the $\mathrm{HNO}_{3}+\mathrm{HF}+$ $\mathrm{H}_{2} \mathrm{O}_{2}$ (3:2:5 in volume) solution is used to dissolve arsenic-bearing amorphous silicate glass. The concentration of As element in the solution is detected after each selective extraction process. Through this method, the content and structure of arsenic-bearing substances in the smelting slag can be obtained and divided exactly. The flowchart of the selectively sequential extraction procedures is shown in Fig. 3.

Table. 2 shows the As concentration of the leaching solution after selectively sequential extraction. It is indicated that the proportion of arsenic compounds (insoluble arsenate, arsenic sulfide, arsenopyrite and amorphous silicate) reaches up to $80.8 \%$, and thereinto, arsenic in amorphous silicate glass accounts for $63.37 \%$. Owing to the high stability of amorphous silicate glass, the smelting slag possesses high selfsolidification behavior of arsenic element.

Table. 2 Arsenic concentration of leaching solution after selectively sequential extraction 


\begin{tabular}{|llllllll|}
\hline Step & SCS & Step 1 & Step 2 & Step 3 & Step 4 & Step 5 & Step 6 \\
\hline $\begin{array}{l}\text { Extracted } \\
\text { components }\end{array}$ & $\begin{array}{l}\text { Water } \\
\text { solubility } \\
\text { arsenate } \\
\text { and } \\
\text { arsenic } \\
\text { oxide }\end{array}$ & $\begin{array}{l}\text { Soluble } \\
\text { crystalline } \\
\text { arsenate } \\
\text { and } \\
\text { adsorbed } \\
\text { arsenic }\end{array}$ & $\begin{array}{l}\text { Insoluble } \\
\text { arsenate }\end{array}$ & $\begin{array}{l}\text { Arsenic } \\
\text { sulfide }\end{array}$ & $\begin{array}{l}\text { Arsenopyrite } \\
\text { Arsenic in } \\
\text { amorphous } \\
\text { silicate } \\
\text { glass }\end{array}$ \\
$\begin{array}{l}\text { Mass fraction } \\
\text { of Arsenic } \\
/(\text { wt.\%) }\end{array}$ & 100 & 3.86 & 15.35 & 12.38 & 2.67 & 2.38 & 63.37 \\
$\begin{array}{l}\text { Arsenic } \\
\text { leaching } \\
\text { concentration } \\
\text { of residue /(g } \\
\left.\mathrm{L}^{-1}\right)\end{array}$ & 25.06 & 15.55 & 3.97 & 0.89 & 0.76 & 0.19 & $/$ \\
\hline
\end{tabular}

"/" undetectable

\subsection{Simulation of slag}

As mentioned above, the slag is composed of magnetite, fayalite and silicate glass phase. Owing to the similar size and structure of $\mathrm{AsO}_{4}{ }^{3-}$ and $\mathrm{SiO}_{4}{ }^{4-}$ units (Reddy and Font 2003), arsenic is easy to enter into the network of silicate glass. Thus, the behavior of arsenic solidification occurs in fayalite and silicate glass phases, rather than in magnetite. Here, calcium arsenate was used to simulate the arsenic bearing phase in the slag, which was formed by the reaction between $\mathrm{Na}_{2} \mathrm{HAsO}_{4}$ and $\mathrm{CaCl}_{2} . \mathrm{Na}_{2} \mathrm{HAsO}_{4}$ was dissolved in deionized water, and $\mathrm{CaCl}_{2}$ was obtained through the reaction between $\mathrm{CaO}$ and $0.1 \mathrm{M} \mathrm{HCl}$ solution. The $\mathrm{Na}_{2} \mathrm{HAsO}_{4}$ and $\mathrm{CaCl}_{2}$ solutions were mixed as the $\mathrm{Ca} / \mathrm{As}$ molar ratio of 1.5 , and then pH was adjusted to 7 ( \pm 0.5 ) by $0.1 \mathrm{M} \mathrm{NaOH}$. Afterwards, the solution was stilled for $24 \mathrm{~h}$ and then filtered. The precipitation was then dried at $80{ }^{\circ} \mathrm{C}$ for $24 \mathrm{~h}$ and finally calcium arsenate was obtained. Besides, as a main product at high temperature in flash smelting furnace, here, fayalite was in-situ formed by $\mathrm{SiO}_{2}, \mathrm{Fe}_{2} \mathrm{O}_{3}$ and $\mathrm{Fe}$ powders, and the reaction equation is presented as follows $\llbracket$

$2 \mathrm{Fe}+2 \mathrm{Fe}_{2} \mathrm{O}_{3}+3 \mathrm{SiO}_{2}=3 \mathrm{Fe}_{2} \mathrm{SiO}_{4} \quad \Delta \mathrm{G}=-90 \mathrm{~kJ}\left(1000^{\circ} \mathrm{C}\right) \sim-98 \mathrm{~kJ}\left(1300^{\circ} \mathrm{C}\right)$

Subsequently, $\mathrm{Fe}, \mathrm{Fe}_{2} \mathrm{O}_{3}$ and $\mathrm{SiO}_{2}$ powders were mixed according to the molar ratio of 2:2:3 with addition of 5 wt.\% calcium arsenate. The mixed powders were blended by a jar mill for a period of $4 \mathrm{~h}$ and compacted in a cylindrical form under a pressure of $30 \mathrm{MPa}$ for $15 \mathrm{~s}$, followed by sintering in air or argon for $4 \mathrm{~h}$ in a tubular furnace. The sintering temperature ranges from $1000{ }^{\circ} \mathrm{C}$ to $1300{ }^{\circ} \mathrm{C}$ with the interval of $100{ }^{\circ} \mathrm{C}$. Afterwards, the powders were cooled to room temperature inside the furnace.

\subsection{Characterization}

Phase constitutions of the slag were characterized by an X-ray diffraction RIGAKU D/Max 2550 PC) analyzer with a Cu Ka source $(\lambda=1.54059 \AA)$ at $40 \mathrm{kV}$ at room temperature. The morphological characteristics of the smelting slag and the simulated slag were characterized by using a scanning electronic microscopy (SEM, 
Zeiss Merlin, operated at $15 \mathrm{kV}$ ) equipped with an energy dispersive X-ray analyzer (EDX). The analysis of chemical composition of slag was carried out by an X-ray fluorescence spectrometer (ARL ADVANT'X, Thermo, USA). X-ray photoelectron spectroscopy (XPS) was performed by Thermo Fisher Scientific ESCALAB 250Xi (Al Ka X-ray source, hv=1486.6 eV).

\subsection{TCLP experiment}

TCLP (Toxicity Characteristic Leaching Procedure) (Jong and Parry 2005) is mainly used to detect the dissolution and migration of heavy metallic elements in solid wastes. The TCLP of smelting slag and simulated slag by extracting arsenic-bearing hazardous components is measured, and then the results are compared with the identification standard for hazardous substances (GB 5085.3-2007).

The extraction agent can be prepared as follows: $5.7 \mathrm{ml}$ acetic acid was added into deionized water, fixed to the volume of $1 \mathrm{~L}$, and guaranteed the $\mathrm{pH}$ value located in the range of $2.88 \pm 0.05$. Then, $2 \mathrm{~g}$ milled slag was added into $40 \mathrm{~mL}$ extraction agent and put into a inverted oscillation device. The solid-to-liquid ratio was $50 \mathrm{~g}$ $\mathrm{L}^{-1}$, and the shaking time was $18 \mathrm{~h}$ at $25^{\circ} \mathrm{C}$. Subsequently, the concentration of As element in the liquid was measured by EDX after separation of solid and liquid.

\subsection{Theoretical calculation}

In order to study the structure and the stability of simulated slag, the first principle molecular dynamics (FPMD) calculation was carried out by using the Vienna ab initio simulation package (VASP) (Kresse and Hafner 1993) based on density functional theory (DFT). The projector-augmented plane wave (PAW) (Kresse and Joubert 1999) approach was used to represent the ion-electron interaction. The electron exchangecorrelation functional was treated by using generalized gradient approximation (GGA) in the form proposed by Perdew, Burke and Ernzerhof (PBE) (Perdew et al. 1996). The wave function was represented by a set of plane wave based on an energy cutoff of $400 \mathrm{eV}$. Two structural models $\left(\mathrm{Ca}_{16} \mathrm{As}_{16} \mathrm{O}_{64} \mathrm{H}_{16}\right.$,

$\left.\mathrm{Ca}_{8} \mathrm{Fe}_{8} \mathrm{As}_{8} \mathrm{Si}_{8} \mathrm{O}_{64} \mathrm{H}_{16}\right)$ with 112 atoms in supercells were constructed. In the MD simulations, the structure was heated to $1600 \mathrm{~K}\left(1327^{\circ} \mathrm{C}\right)$, each MD simulation in NPT ensemble lasted for 24ps with a time step of $1.0 \mathrm{fs}$, and the temperature was controlled by using the Nosé-Hoover method (Martyna et al. 1992). Owing to understand the atomic diffusion at sintering temperature, the mean square displacement of atoms in high temperature structure was calculated from the equation:

$$
M S D=\frac{1}{N} \sum_{i=1}^{N}\left\langle r_{i}(t)-r_{i}(0)\right\rangle^{2}
$$

where $r_{i}$ is the position of the atom, and brackets represent the average of all atoms in the group. After sintering at $1600 \mathrm{~K}$, the structure was gradually cooled to $300 \mathrm{~K}$, and then annealed at $300 \mathrm{~K}$ for at least $24 \mathrm{ps}$.

\section{Results And Discussion}

\subsection{Microstructures and phase determination of the simulated slag}


Fig. 4 shows the microstructures of the simulated slag sintered in air at different temperatures. The individual particles can be detected when sintered at $1000^{\circ} \mathrm{C}$, which indicates that the particles have not been melted. When the sintering temperature rises up to $1100{ }^{\circ} \mathrm{C}$, the particles are partially melted and evident sintering necking can be seen. Besides, the size of particle increases obviously. When the temperature reaches up to $1200{ }^{\circ} \mathrm{C}$ and $1300{ }^{\circ} \mathrm{C}$, the microstructure shows the solidification structure of molten liquid, suggesting that severe reaction may occur during the sintering process. Besides, the locally globular protrusions can be clearly seen on the surface of the simulated slag even sintered at $1300{ }^{\circ} \mathrm{C}$.

Fig. 5 shows the microstructure of simulated slag sintered in argon at different temperature. The slag shows two specific morphologies: (I) When the sintering temperature is lower than $1100{ }^{\circ} \mathrm{C}$, the particles are relatively independent with lots of pores, which means that the reaction is insufficient. (II) The particles are melted and then form densified products with smooth and flat morphology when sintered at 1200 and 1300 ${ }^{\circ} \mathrm{C}$. Compared with the simulated slag sintered in air, it can be inferred that the reaction is severer in argon, because of the disappearance of locally globular protrusions.

Fig. 6 shows the XRD spectrum of simulated slag sintered at different temperature in air. It obviously shows that $\mathrm{Fe}_{2} \mathrm{O}_{3}$ and $\mathrm{Fe}_{3} \mathrm{O}_{4}$ peaks occur when sintered at 1100 and $1200{ }^{\circ} \mathrm{C}$ rather than fayalite phase, and also remains the grainy structure. The high content of oxygen inhibits the formation of fayalite and/or promotes the oxidization of fayalite. Afterwards, the Fe-Si oxide phase $\left(\left(\mathrm{Fe}_{0.914} \mathrm{Si}_{0.086}\right)\left(\mathrm{Fe}_{0.998} \mathrm{Si}_{0.002}\right)_{2} \mathrm{O}_{4}, \mathrm{PDF} \# 89\right.$ 6227, referred to as " $\mathrm{Fe}_{3-\mathrm{x}} \mathrm{Si}_{\mathrm{x}} \mathrm{O}_{4}$ " hereafter) is formed owing to the further reaction among silica, $\mathrm{Fe}_{2} \mathrm{O}_{3}$ and $\mathrm{Fe}_{3} \mathrm{O}_{4}$ particles. However, some silica particles can also be detected in the simulated slag when sintered at $1300{ }^{\circ} \mathrm{C}$ because of the high melting point and relatively low diffusion rate of $\mathrm{SiO}_{2}$.

When sintered in argon, fayalite phase can be formed even at $100{ }^{\circ} \mathrm{C}$, as the XRD spectrum shown in Fig. 7 . However, silica particles can not be reacted completely, and therefore inhibit the diffusion of atoms in the simulated slag. Thus, the simulated slag presents porous morphology when sintered below $1100{ }^{\circ} \mathrm{C}$. The $\mathrm{Fe}_{3} \mathrm{O}_{4}$ and silica phases disappear when the sintering temperature reaches up to $1200{ }^{\circ} \mathrm{C}$, which can also be confirmed by the smooth and flat morphology of the simulated slag. In addition, the diffraction peaks of arsenic-bearing phases can not be found because of the relatively low content of arsenic and its compound.

\subsection{TCLP tests}

TCLP tests have been utilized to evaluate the stabilization of As elements inside the simulated slag sintered at different temperature and atmosphere, as shown in Fig. 8. It can be seen that the leached arsenic concentration of the simulated slag sintered in air at $1000{ }^{\circ} \mathrm{C}$ and $1100{ }^{\circ} \mathrm{C}$ reaches up to 188.7 and $243.3 \mathrm{mg}$ $\mathrm{L}^{-1}$, respectively, much higher than the limitation of arsenic concentration $\left(5.0 \mathrm{mg} \mathrm{L}^{-1}\right)$ stipulated by the identification standard for hazardous substances (GB 5085.3-2007). The leaching concentration of As increases when the sintering temperature improves from $1000^{\circ} \mathrm{C}$ to $1100{ }^{\circ} \mathrm{C}$ in air, which can be attributed to the improved mobility of arsenic atoms. When sintered at $1200{ }^{\circ} \mathrm{C}$ and $1300{ }^{\circ} \mathrm{C}$ in air, the leaching concentration of arsenic is as low as 2.916 and $0.339 \mathrm{mg} \mathrm{L}^{-1}$, respectively. It can be inferred that As elements are stabilized in the simulated slag. As for the simulated slag sintered in argon, the leached arsenic concentration satisfies the identification standard for hazardous substances except sintered at $1000{ }^{\circ} \mathrm{C}$. 
According to the XRD spectrum, we can confirm that fayalite phase possesses better As stabilization ability than that of Fe-Si oxide phase.

\subsection{XPS analysis of the simulated slag}

In order to study the valence state of As and Si elements inside the simulated slag, XPS analysis has been applied. As shown in Fig. 9, the peak of Si2p shifts towards to the low binding energy with increasing temperature, indicating the increasing of the valence electron density of Si atoms (Dalby et al. 2007). The research (Zhao et al. 2016) certifies that the Si-O-Si bindings can be translated into Si-O-Fe and Si-O-As bindings when arsenic atoms are introduced into glass. As can be seen in Fig. 9(a), there exists two types of Si (Zhao et al. 2016) when sintered at $1000^{\circ} \mathrm{C}$ in air: One is the bond for bridging oxygen which occurs at high binding energy (103.59 eV) and the other is the bond for non-bridging oxygen at low binding energy $(102.47 \mathrm{eV})$. The relative percentages of these two types of Si are $81.4 \%$ and $18.6 \%$, respectively. Thus, it can be deduced that silicon atoms existed as Si-O-Si bond do not link to other atoms. When sintering temperature reaches to $1200^{\circ} \mathrm{C}$, as show in Fig. 9(b), Si atoms exist as Si-O-Si, Si-O-Fe and Si-O-As bindings, and the corresponding percentages are $65.34 \%, 27.5 \%$ and $7.16 \%$, respectively. The existence of Si-O-Fe bond is due to the formation of Fe-Si oxides during sintering process. When sintered at $1100{ }^{\circ} \mathrm{C}$ and $1200{ }^{\circ} \mathrm{C}$ in argon, as show in Fig. 9(c) and (d), the proportion of Si-O-As are $13.75 \%$ and $15.76 \%$, respectively. It is evidently that with the increase of temperature, Si-O-Si bonds can be replaced by Si-O-As bonds. The Si-O-As bond is rather stable and thereby reduces the leaching concentration of As in solution.

The spectrum of As3d under different conditions is shown in Fig. 10. According to the previous research (Bang et al. 2005), the binding energy of $\mathrm{AsO}_{4}{ }^{3-}$ and $\mathrm{HAsO}_{4}{ }^{2-}$ was at $44.9 \mathrm{eV}$ and $45.5 \mathrm{eV}$, respectively. In this work ,only $\mathrm{As}(\mathrm{V})$ peak $\left(\mathrm{AsO}_{4}{ }^{3-}\right)$ can be detected in As3d spectrum when sintered in air. The peak is shift towards to the low binding energy with the increase of temperature. It is due to the electron density of As is higher than Si in Si-O-As, causing the electron density around As atom increases and the binding energy of arsenic shift to lower energy. It can be deduced that the arsenic have participated in the glass structure in the form of Si-O-As. In argon, XPS spectra of As in Fig. 10 shows that the binding energy at $43.8 \mathrm{eV}$ is regarded as As (III), while the binding energy at $44.9 \mathrm{eV}$ is presented as $\mathrm{AsO}_{4}{ }^{3-}$. The relative percentages of As (III) at these two temperatures are $29.3 \%$ and $20.7 \%$, respectively. As (III) can be formed through the reduction of As $(\nabla)$ by Fe. The As(V) is more stable and less toxic than As(III) (Wang et al. 2019; Xiu et al. 2016), and thus it is favorable to immobilize arsenic as $\mathrm{As}(\mathrm{V})$. With the increase of temperature, the percentage of As (III) decreases. Therefore, it is favorable for arsenic compound to replace $\mathrm{SiO}_{4}$ and form As-O-Si covalent bond, resulting in the enhanced properties of arsenic solidification and stabilization of the simulated slag.

\subsection{Theoretical calculation}

In order to identify the promotional effect of diffusion rate by formed fayalite phase, the FPMD calculation is applied. Here, the $\left(\mathrm{Ca}_{0.5} \mathrm{Fe}_{0.5}\right) \mathrm{H}\left(\mathrm{As}_{0.5} \mathrm{Si}_{0.5}\right) \mathrm{O}_{4}$ structure is used to simulate the mixture of calcium hydrogen arsenate $\left(\mathrm{CaHAsO}_{4}\right)$ and fayalite. The diffusion rate and the mean square displacements of different atoms can be calculated according to the following equation: 


$$
M S D=\frac{1}{N} \sum_{i=1}^{N}\left\langle r_{i}(t)-r_{i}(0)\right\rangle^{2}
$$

Where $r_{i}$ is the displacement of the atom and $t$ represents the time.

Fig.11 (a) and (b) show the mean square displacement of different atoms in $\mathrm{CaHAsO}_{4}$ and $\left(\mathrm{Ca}_{0.5} \mathrm{Fe}_{0.5}\right) \mathrm{H}\left(\mathrm{As}_{0.5} \mathrm{Si}_{0.5}\right) \mathrm{O}_{4}$ structures, respectively, which can directly reflect the atomic diffusion behaviors (Wu 2004). The results show that the atom diffusion in $\left(\mathrm{Ca}_{0.5} \mathrm{Fe}_{0.5}\right) \mathrm{H}\left(\mathrm{As}_{0.5} \mathrm{Si}_{0.5}\right) \mathrm{O}_{4}$ structure is evidently higher than that in $\mathrm{CaHAsO}_{4}$, which can be inferred that the fayalite phase can promote the movement of atoms and therefore enhance the diffusion rate. As discussed above, the simulated slag shows smooth and flat morphology sintered in argon while that possesses locally globular protrusions sintered in air, which can be attributed to the formation of fayalite phase and thus accelerate the diffusion rate in argon. However, the promotional effect of diffusion rate by $\mathrm{Fe}_{2} \mathrm{O}_{3}$ and $\mathrm{Fe}_{3} \mathrm{O}_{4}$ phases are evidently lower than that of fayalite phase, and thus, the melting temperature of simulated slag is rather high when sintered in air.

Fig. 12 shows the simulated structure of $\left(\mathrm{Ca}_{0.5} \mathrm{Fe}_{0.5}\right) \mathrm{H}\left(\mathrm{As}_{0.5} \mathrm{Si}_{0.5}\right) \mathrm{O}_{4}$ by sintering of $\mathrm{CaHASO}_{4}$ and $\mathrm{Fe}_{2} \mathrm{SiO}_{4}$ powders. The $\mathrm{AsO}_{4}$ and $\mathrm{SiO}_{4}$ tetrahedrons can be seen in the simulated structure, reflecting the occurrence of As-O-Si covalent bond. As mentioned above, As-O-Si covalent bond is relatively stable. Therefore, As atoms can not escape easily from the crystal, and therefore inhibit the leaching of As atoms.

In summary, we can confirm that the stabilizing ability of As elements is improved when the content of oxygen is relatively low, which can be ascribed as the following reasons: (I) The fayalite phase can be preserved at high temperature with low content of oxygen; (II) The fayalite phase inside the slag can reduce the melting temperature and enhance the diffusion rate; (III) As atom can take place of Si atom through diffusion process and form $\mathrm{AsO}_{4}$ tetrahedron; (IV) The stability of Si-O-As covalent bond is rather high, which can inhibit the extraction of As from the slag.

\section{Conclusion}

1. The simulated slag forms Fe-Si oxide sintered in air, and the TCLP results can stipulate the identification standard for hazardous substances when the sintering temperature exceeds $120{ }^{\circ} \mathrm{C}$.

2. In argon atmosphere, the sintered production is fayalite, which has excellent arsenic solidification ability when the sintering temperature is over $1100{ }^{\circ} \mathrm{C}$.

3. The fayalite phase can promote the movement of atoms and expedite the formation of Si-O-As bond.

4. $\mathrm{AsO}_{4}$ can take place of $\mathrm{SiO}_{4}$ tetrahedron with high stability, resulting in the high arsenic atom immobilization in fayalite.

\section{Declarations}

\section{Acknowledgments}


The authors are very grateful to Tongling Nonferrous Metals Group (CN) for providing the related data and samples. The financial support from the National Natural Science Foundation of China (NO. 51874257, 51374185) was also greatly appreciated.

\section{Compliance with ethical standards}

Ethics approval and consent to participate: Not applicable.

Consent for publication: Not applicable.

\section{Authors' contributions}

Shenghang Xu: Methodology, Investigation.

Bin Hu: Formal analysis, Investigation.

Huibin Zhang: Investigation, Writing-review \& editing.

Min Wu: Investigation, Writing-review \& editing.

Yanan Wang: Investigation, Writing-review \& editing.

Yuzheng He: Software, Supervision.

Huazhen Cao: Formal analysis, Investigation.

Jun Zhou[Project administration.

Guoqu Zheng: Writing-review \& editing, Project administration.

\section{Funding}

The authors thank the National Natural Science Foundation of China for financial support granted to carry out this work.

\section{Competing interests}

The authors declare that they have no competing interests.

\section{Data availability}

All data generated or analyzed during this study are included in this published article.

\section{Declaration of Competing Interest}

The authors declare that they have no known competing financial interests or personal relationships that could have appeared to influence the work reported in this paper. 


\section{References}

1. Bang S, Johnson MD, Korfiatis GP, Meng X (2005) Chemical reactions between arsenic and zero-valent iron in water. Water Res 39(5): 763-770 http://doi.org/10.1016/j.watres.2004.12.022

2. Dalby KN, Nesbitt HW, Zakaznova-Herzog VP, King PL (2007) Resolution of bridging oxygen signals from 0 1s spectra of silicate glasses using XPS: Implications for $\mathrm{O}$ and Si speciation. Geochimica et Cosmochimica Acta 71(17): 4297-4313 http://doi.org/10.1016/j.gca.2007.07.005

3. Drahota P, Grosslova Z, Kindlova H (2014) Selectivity assessment of an arsenic sequential extraction procedure for evaluating mobility in mine wastes. Analytica Chimica Acta 839: 34-43 http://doi.org/10.1016/j.aca.2014.06.022

4. Jaarsveld JGSV, Deventer JSJV, LORENZEN L (1997) The potential use of geopolymeric materials to immobilise toxic metals: Part I. Theory and applications. Miner Eng 10(7): 659-669 http://doi.org/10.1016/S0892-6875(97)00046-0

5. Jaarsveld JGSV, Deventer JSJV, Schwartzman A (1999) The potential use of geopolymeric materials to immobilise toxic metals: Part II. Material and leaching characteristics. Miner Eng 12(1): 75-91 http://doi.org/10.1016/S0892-6875(98)00121-6

6. Jong T, Parry DL (2005) Evaluation of the stability of arsenic immobilized by microbial sulfate reduction using TCLP extractions and long-term leaching techniques. Chemosphere 60(2): 254-265 http://doi.org/10.1016/j.chemosphere.2004.12.046

7. Kresse G, Hafner J (1993) Ab Initio Molecular Dynamics for Open-Shell Transition Metal. Physical review B, Condensed matter 48(17): 13115-13118 http://doi.org/10.1103/PhysRevB.48.13115

8. Kresse G, Joubert D (1999) From ultrasoft pseudopotentials to the projector augmented-wave method. Physical Review B 59(3): 1758-1775 http://doi.org/10.1103/PhysRevB.59.1758

9. Kundu S, Gupta AK (2008) Immobilization and leaching characteristics of arsenic from cement and/or lime solidified/stabilized spent adsorbent containing arsenic. J Hazard Mater 153(1-2): 434-443 http://doi.org/10.1016/j.jhazmat.2007.08.073

10. Li Y, Xu Y, Zhu X, Wang H, Qi X, Li K, Wei Y (2018) Solidification/stabilization of arsenic-bearing gypsum sludge using Portland cement: precalcination effect and arsenic immobilization mechanism. The Chinese Journal of Process Engineering 18(S1): 111-121 http://doi.org/10.12034/j.issn.1009606X.20180108

11. Liu D et al. (2018) Co-treatment of flotation waste, neutralization sludge, and arsenic-containing gypsum sludge from copper smelting: solidification/stabilization of arsenic and heavy metals with minimal cement clinker. Environ Sci Pollut Res 25(8): $7600-7607$ http://doi.org/10.1007/s11356-017-1084-x

12. Luo Z, Zhou X, Jia Q, Zhou Y, Zhang Z (2015) Solidification/immobilization of calcium arsenate waste using phosphorous slag based geopolymers. Journal of the Chinese Ceramic Society 43(5): 699-704 http://doi.org/10.14062/j.issn.0454-5648.2015.05.21

13. Lv G, Zhang F (2018) Behavior, distribution and control measures of Ausmelt Copper smelting process of arsenic. World Nonferrous Metals 07: 11-13 http://doi.org/10.3969/j.issn.1002-5065.2018.07.005 
14. Martyna GJ, Klein ML, Tuckerman M (1992) Nosé-Hoover chains: The canonical ensemble via continuous dynamics. Journal of Chemical Physics 97(4): 2635-2643 http://doi.org/10.1063/1.463940

15. Pantuzzo FL, Ciminelli VST (2010) Arsenic association and stability in long-term disposed arsenic residues. Water Res 44(19): 5631-5640 http://doi.org/10.1016/j.watres.2010.07.011

16. Perdew J, Burke K, Ernzerhof M (1996) Generalized Gradient Approximation Made Simple. Physical review letters 77(18) http://doi.org/10.1103/PhysRevLett.77.3865

17. Reddy RG, Font JM (2003) Arsenate Capacities of Copper Smelting Slags. Metallurgical \& Materials Transactions B 34(5): 567-571 http://doi.org/10.1007/s11663-003-0025-x

18. Shi G, Zhou X, He H, Zhang M, Zhou Y (2017) Solidification of arsenic-containing solid wastes using phosphorus slag-fly ash based geopolymer. Chinese Journal of Environmental Engineering 11(1): 546551 http://doi.org/10.12030/j.cjee.201606066

19. Shi M, Liang Y, Chai L, Min X, Zhao Z, Yang S (2015) Raman and FTIR spectra of modified iron phosphate glasses containing arsenic. Journal of Molecular Structure 1081: 389-394 http://doi.org/10.1016/j.molstruc.2014.10.061

20. Sullivan C, Tyrer M, Cheeseman CR, Graham NJ (2010) Disposal of water treatment wastes containing arsenic - a review. Science of the Total Environment 408(8): 1770-1778 http://doi.org/10.1016/j.scitotenv.2010.01.010

21. Tessier AP, Campbell PGC, Bisson MX (1979) Sequential extraction procedure for the speciation of particulate trace metals. Analytical Chemistry 51(7): 844-851 http://doi.org/10.1021/ac50043a017

22. Vandecasteele C, Dutré V, Geysen D, Wauters G (2002) Solidification/stabilisation of arsenic bearing fly ash from the metallurgical industry. Immobilisation mechanism of arsenic. Waste Manag 22(2): 143-146 http://doi.org/10.1016/S0956-053X(01)00062-9

23. Wang L et al. (2019) Mechanistic insights into red mud, blast furnace slag, or metakaolin-assisted stabilization/solidification of arsenic-contaminated sediment. Environ Int 133(Pt B) http://doi.org/10.1016/j.envint.2019.105247

24. Wu Y (2004) Theoretical studies on the micro-structure of molten silicates and its relation with the macro-properties. Shanghai University

25. Xiu W et al. (2016) Stimulation of Fe(II) Oxidation, Biogenic Lepidocrocite Formation, and Arsenic Immobilization by Pseudogulbenkiania Sp. Strain 2002. Environ Sci Technol 50(12) http://doi.org/10.1021/acs.est.6b00562

26. Xu J, Zhou Y, Tang R (2006) Study on the solidification of heavy metals by fly ash based geopolymers. Journal of Building Materials 9(3): 341-346 http://doi.org/10.1360/cjcp2006.19(5).463.6

27. Yang J, Liu Q, Chen Q, Li Y (2014) Chinese copper mining supply capacity in the next 10 years. China Mining Magazine 23(10): 1-4 http://doi.org/10.3969/j.issn.1004-4051.2014.10.001

28. Yin T, Yang R, Du J, Shi Y (2019) Effects of acid and phosphate on arsenic solidification in a phosphogypsum-based cement backfill process. RSC Advances 9: 28095-28101 http://doi.org/10.1039/C9RA04624K

29. Yoon IH, Moon DH, Kim KW, Lee KY, Lee JH, Kim MG (2010) Mechanism for the stabilization/solidification of arsenic-contaminated soils with Portland cement and cement kiln dust. J 
Environ Manag 91(11): 2322-2328 http://doi.org/10.1016/j.jenvman.2010.06.018

30. Zhang H, He Y, Hu J, Wang Y, Cao H, Zhou J, Zheng G (2020) Assessment of selective sequential extraction procedure for determining arsenic partitioning in copper slag. Transactions of Nonferrous Metals Society of China 30(10): 2823-2835 http://doi.org/10.1016/s1003-6326(20)65424-3

31. Zhang Z, Yuan L, Huang L, Xu Z (2019) Trend and recovery of arsenic, antimony and bismuth in copper smelting. Nonferrous Metals Science Engineering 10(1): 13-19

http://doi.org/10.13264/j.cnki.ysjskx.2019.01.003

32. Zhao Z, Chai L, Peng B, Liang Y, He Y, Yan Z (2017) Arsenic vitrification by copper slag based glass: Mechanism and stability studies. Journal of Non-Crystalline Solids 466-467: 21-28 http://doi.org/10.1016/j.jnoncrysol.2017.03.039

33. Zhao Z, Liang Y, Min X, Chai L, Shi M, Zhou B (2015) The effects of antimony oxide on the structure of iron phosphate glass for the immobilisation of arsenic. Glass Technology: European Journal of Glass Science and Technology Part A 56(6): 196-202 http://doi.org/10.13036/17533546.56.6.196

34. Zhao Z, Song Y, Min X, Liang Y, Chai L, Shi M (2016) XPS and FTIR studies of sodium arsenate vitrification by cullet. Journal of Non-Crystalline Solids 452: 238-244 http://doi.org/10.1016/j.jnoncrysol.2016.08.028

35. Zheng C, Lin D (2015) As, Sb, Bi, Pb flow direction and distribution in flash smelting system. China Nonferrous Metallurgy 40(03): 15-18 http://doi.org/CNKI:SUN:YSYL.0.2015-03-008

\section{Figures}
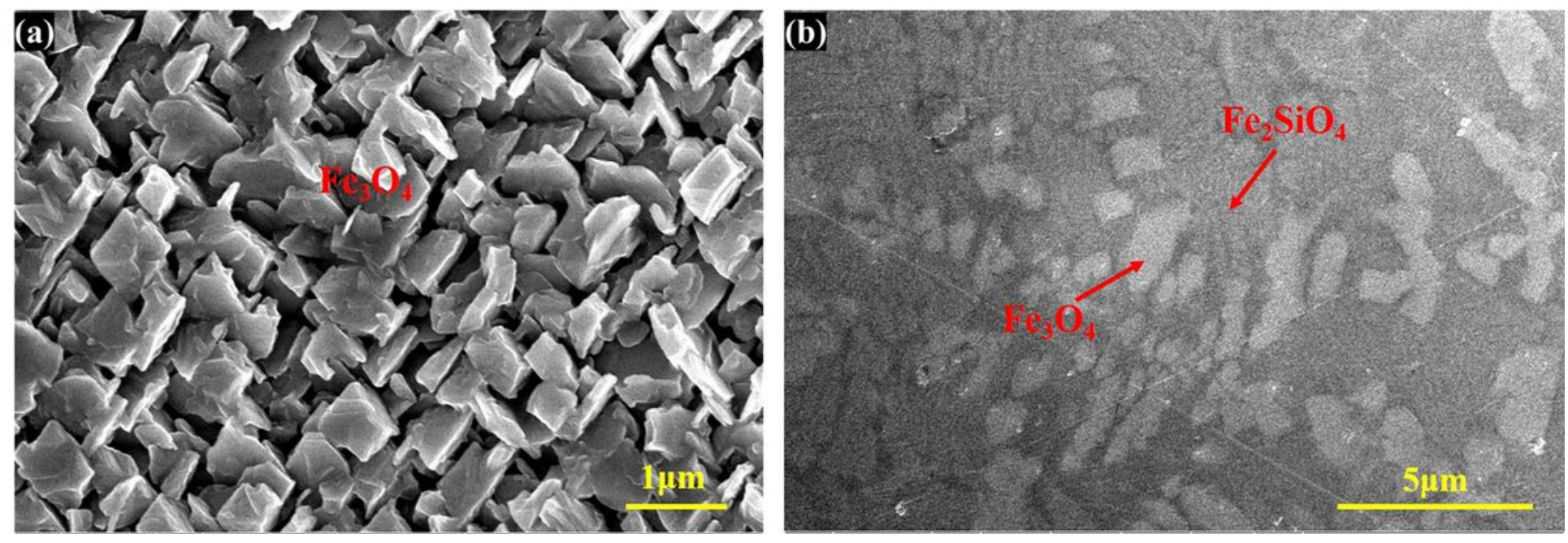

Figure 1

SEM images of (a) Surface morphology of slag; (b) Internal microstructure of slag. 


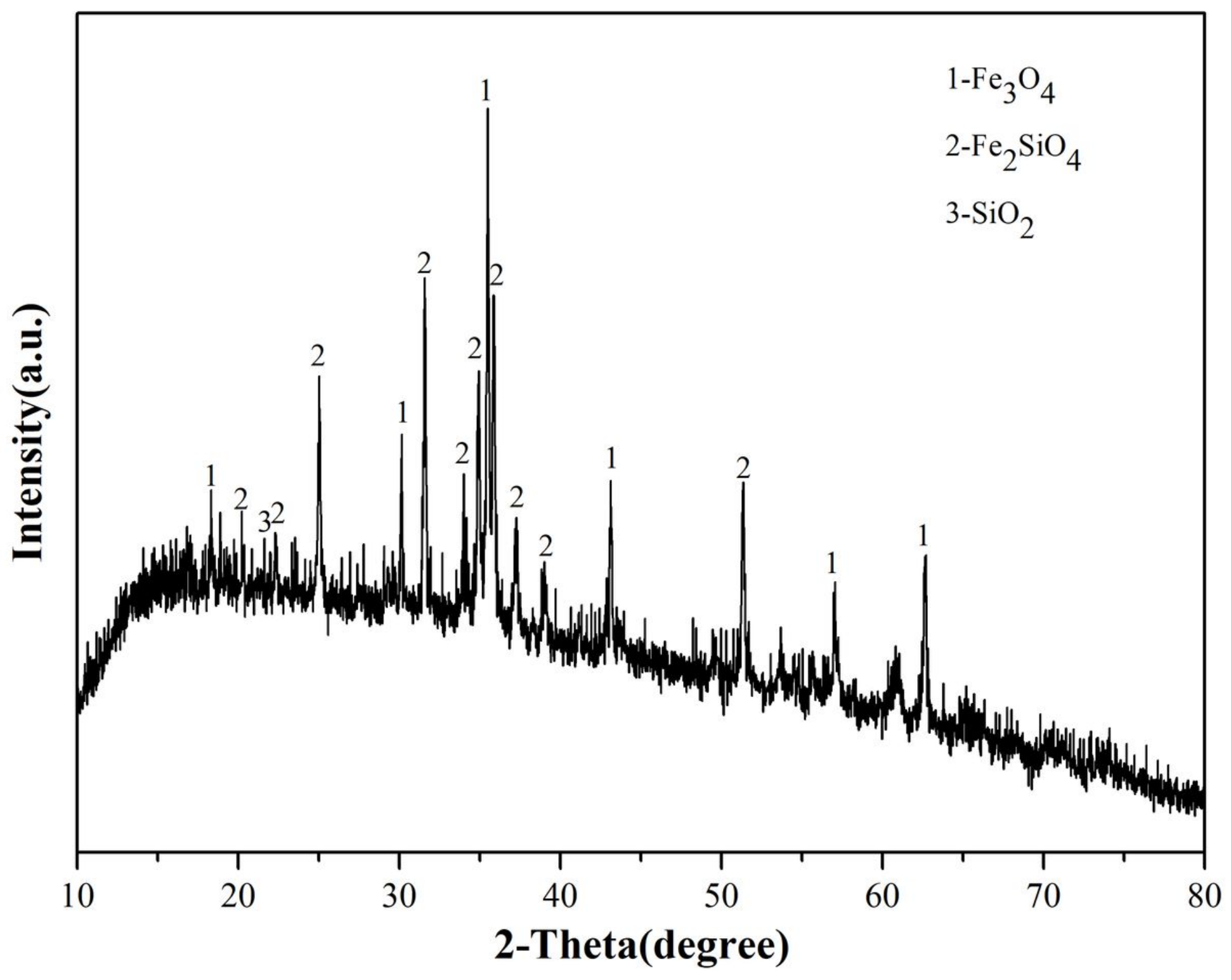

Figure 2

XRD spectrum of arsenic-bearing slag.

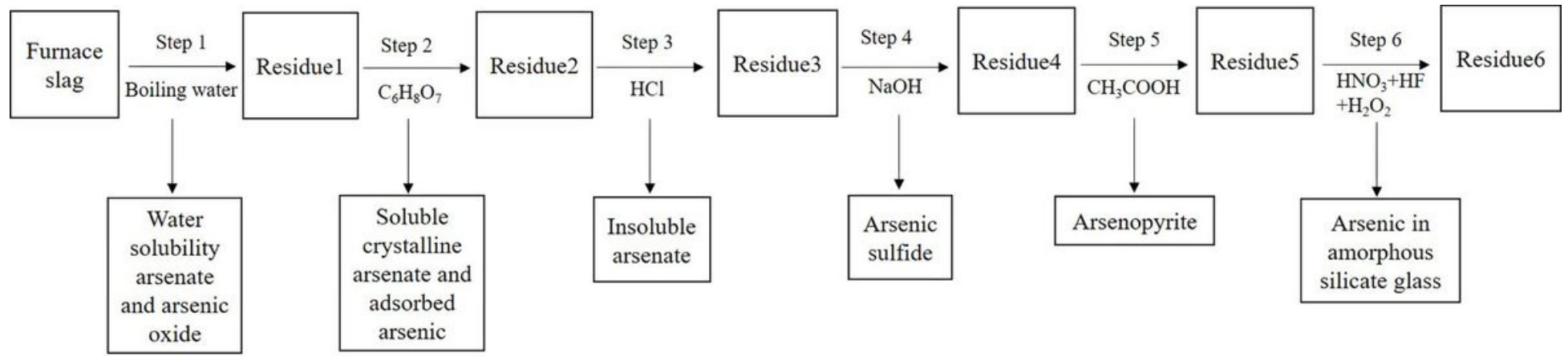

Figure 3

Flowchart of the selectively sequential extraction procedures. 

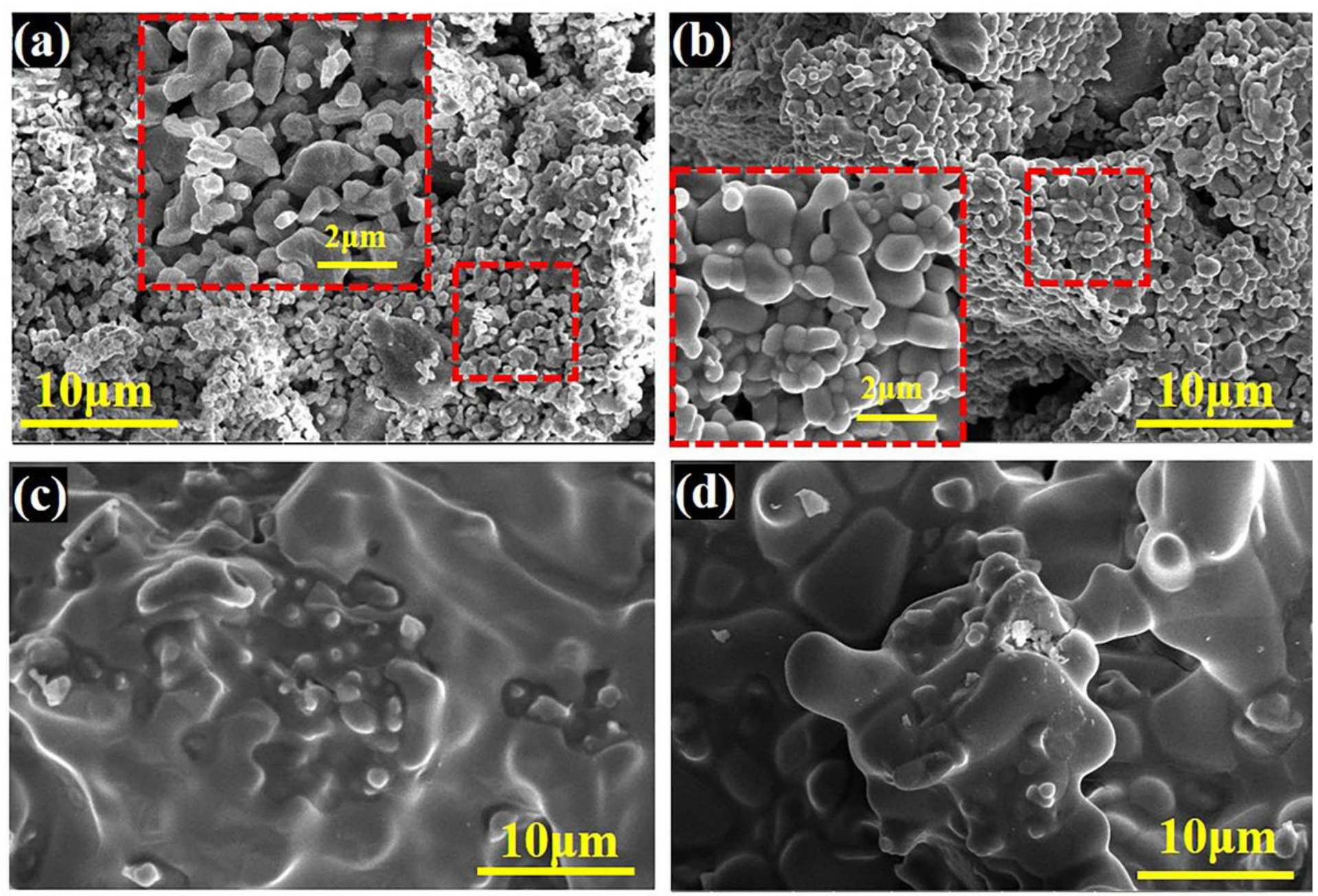

Figure 4

The SEM images of the simulated slag sintered at different temperature in air: (a) $1000{ }^{\circ} \mathrm{C}$; (b) $1100{ }^{\circ} \mathrm{C}$; (c) $1200{ }^{\circ} \mathrm{C}$ and (d) $1300{ }^{\circ} \mathrm{C}$. 

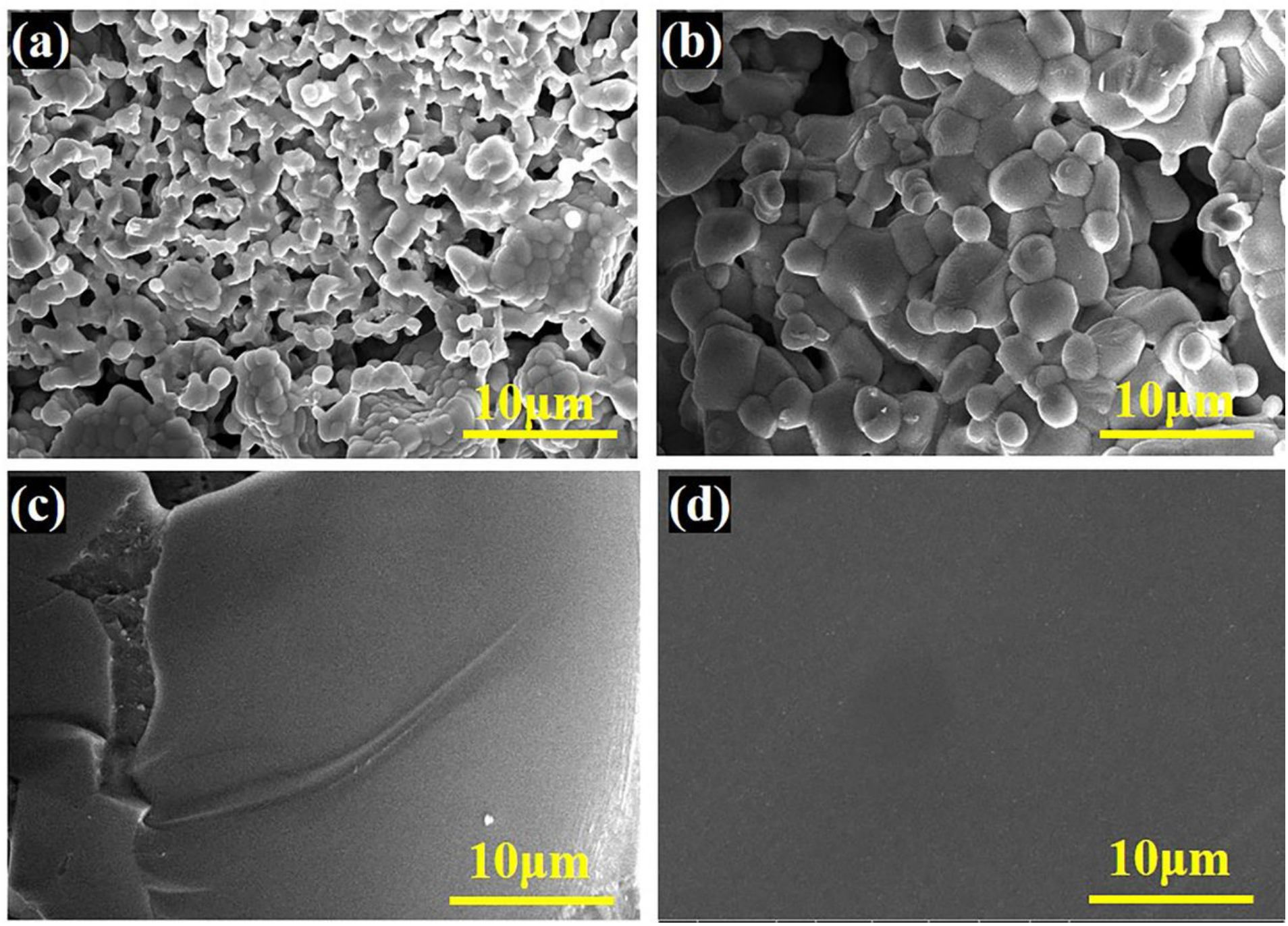

$10 \mu \mathrm{m}$

Figure 5

The SEM images of the simulated slag sintered at different temperature in argon: (a) $1000{ }^{\circ} \mathrm{C}$; (b) $1100{ }^{\circ} \mathrm{C}$; (c) $1200{ }^{\circ} \mathrm{C}$ and (d) $1300{ }^{\circ} \mathrm{C}$. 


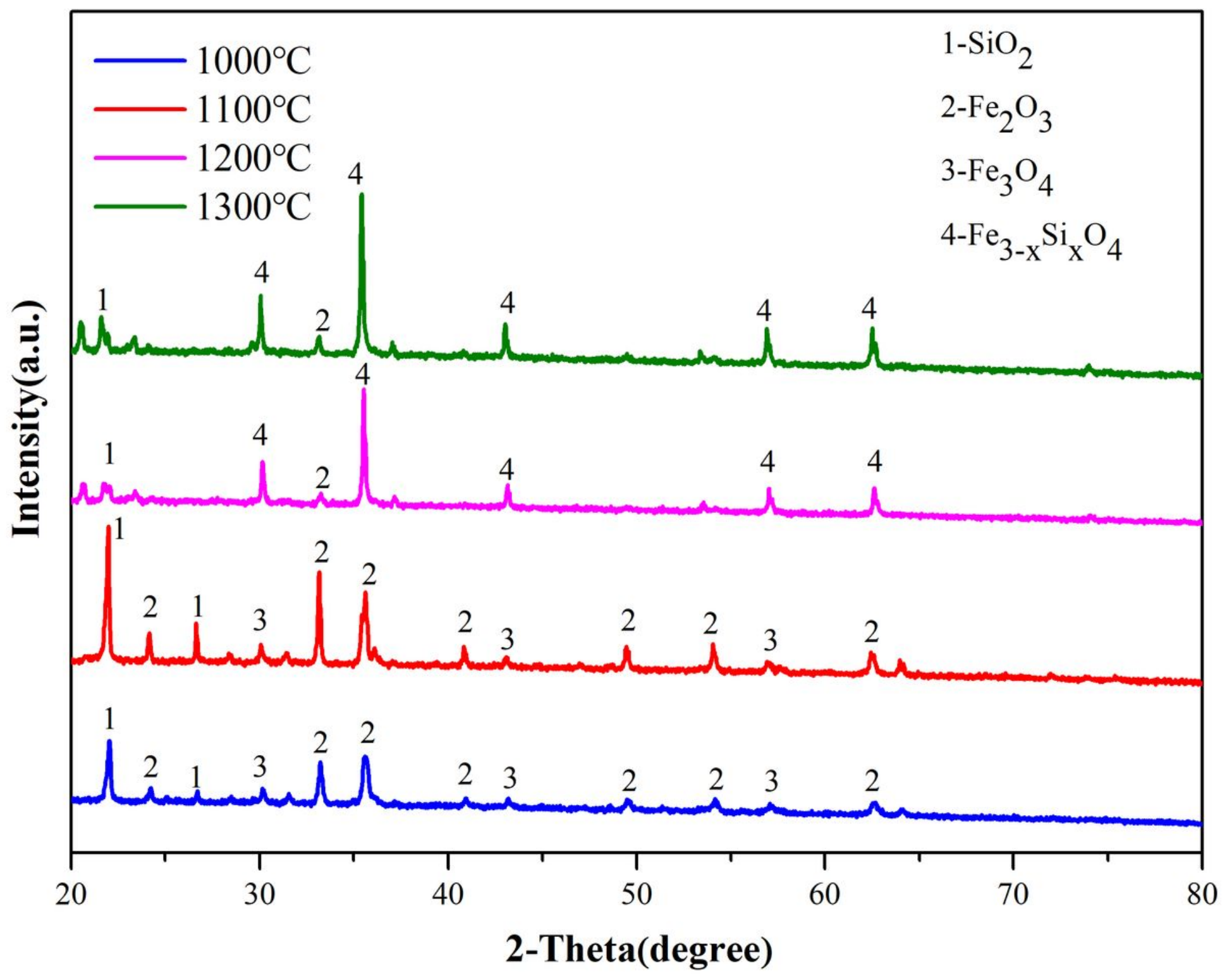

Figure 6

XRD spectrum of simulated slag sintered at different temperature in air. 


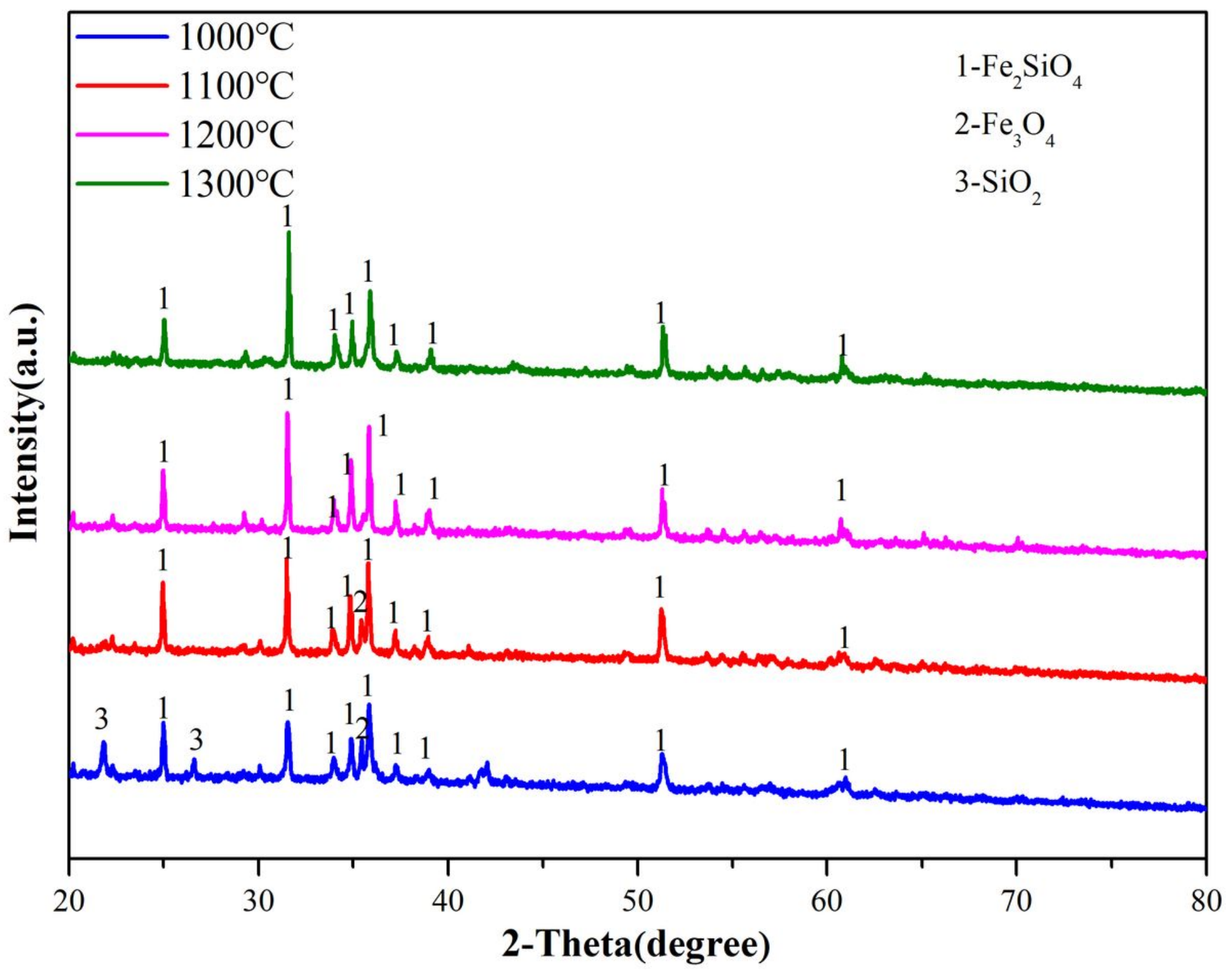

Figure 7

XRD spectrum of simulated slag sintered at different temperature in argon. 


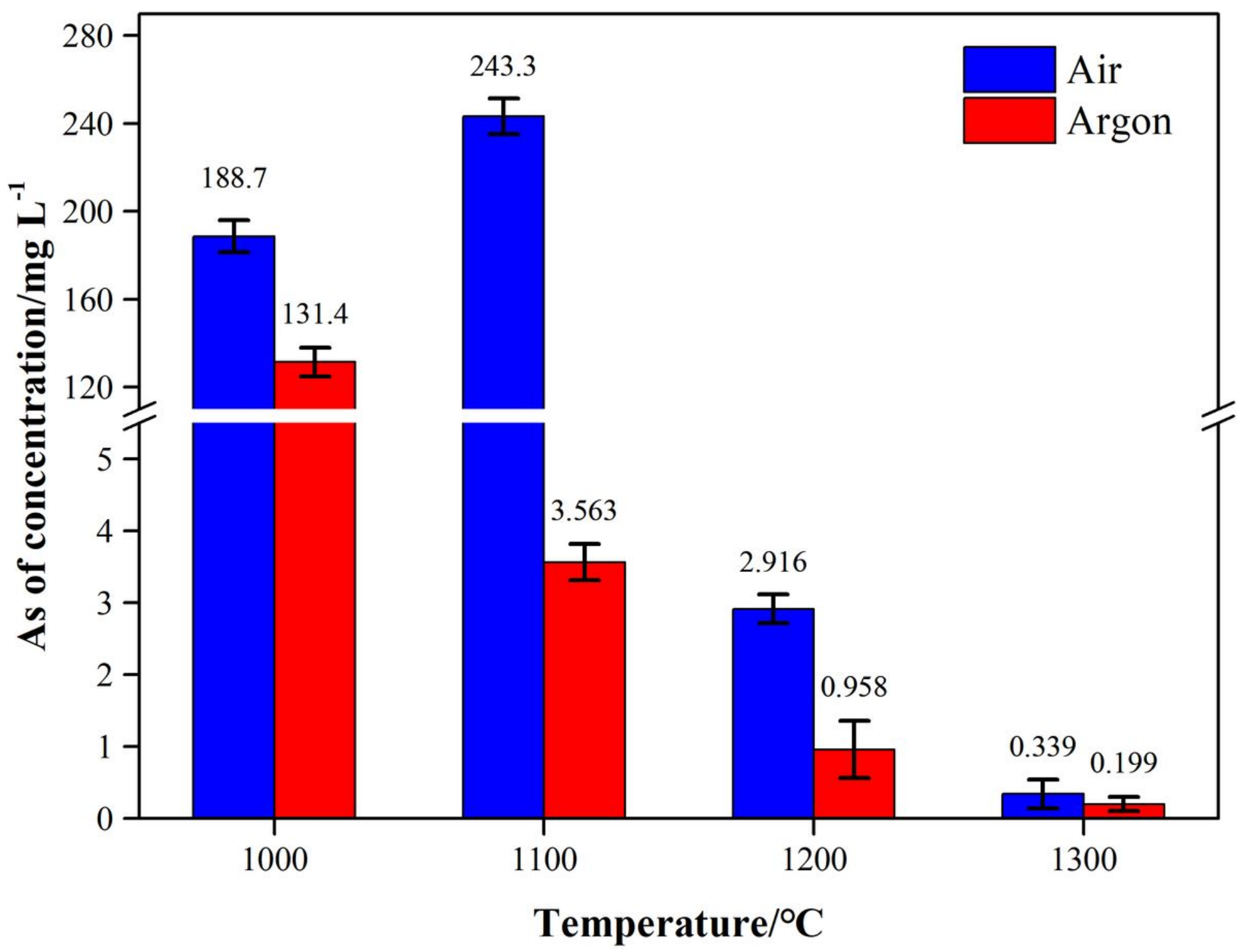

Figure 8

Leaching concentration of arsenic of different simulated slags through TCLP tests. 

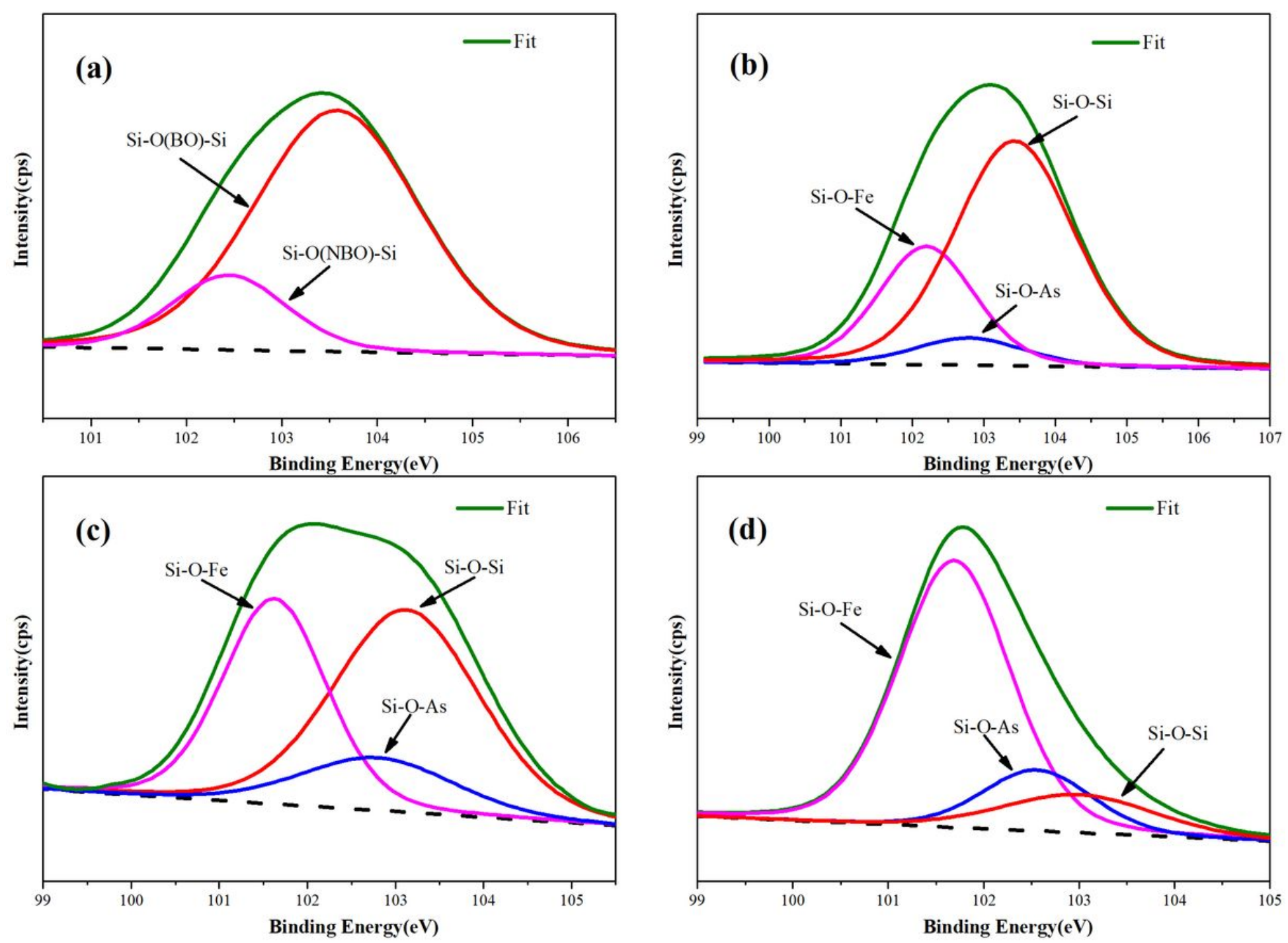

Figure 9

Si2p spectra of different samples: (a) $1100{ }^{\circ} \mathrm{C}$ in air; (b) $1200{ }^{\circ} \mathrm{C}$ in air; (c) $1100{ }^{\circ} \mathrm{C}$ in argon; (d) $1200{ }^{\circ} \mathrm{C}$ in argon. 

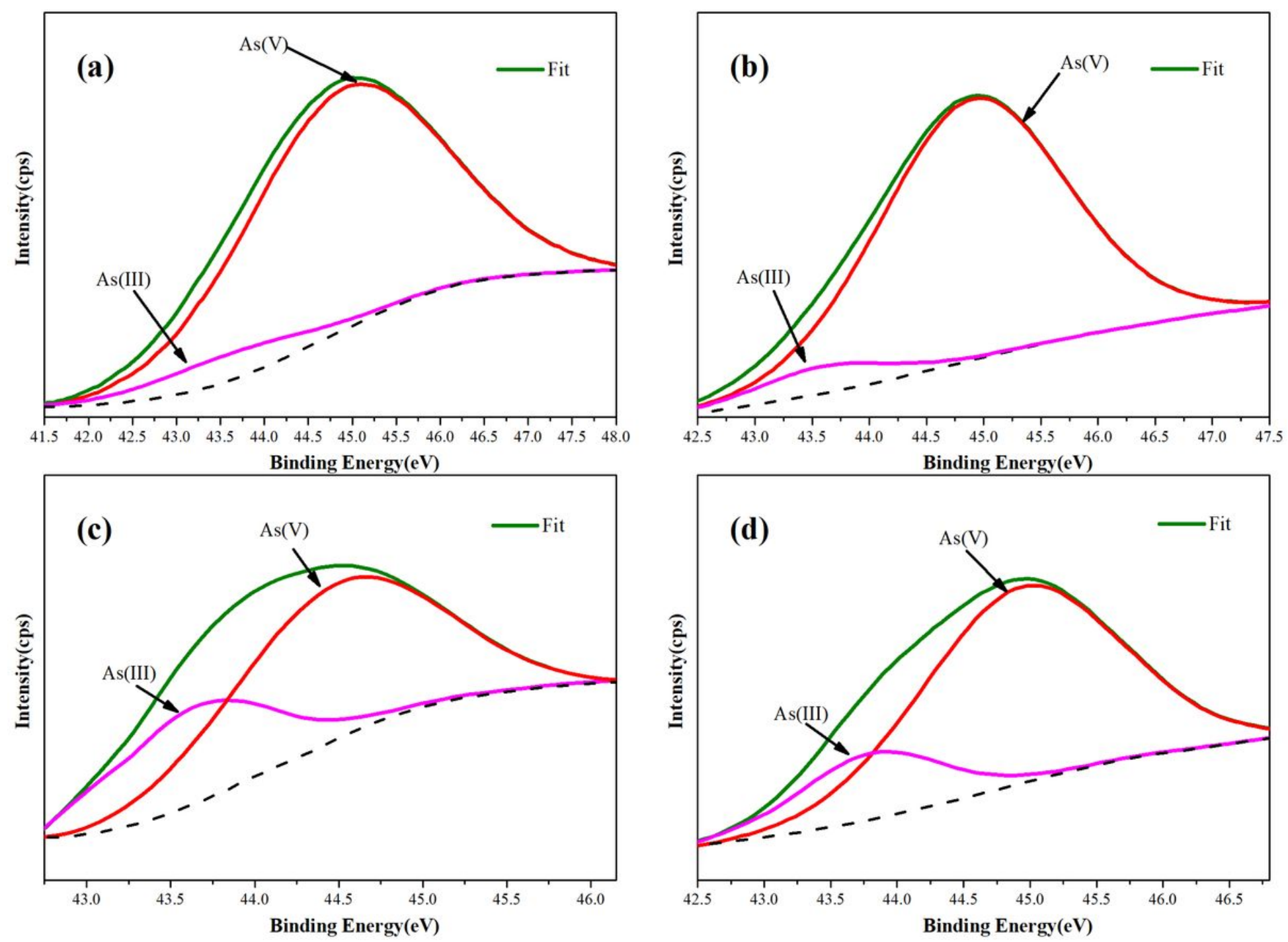

Figure 10

As3d spectra of different samples: (a) $1100^{\circ} \mathrm{C}$ in air; (b) $1200^{\circ} \mathrm{C}$ in air; (c) $1100^{\circ} \mathrm{C}$-argon; (d) $1200^{\circ} \mathrm{C}$-argon. 


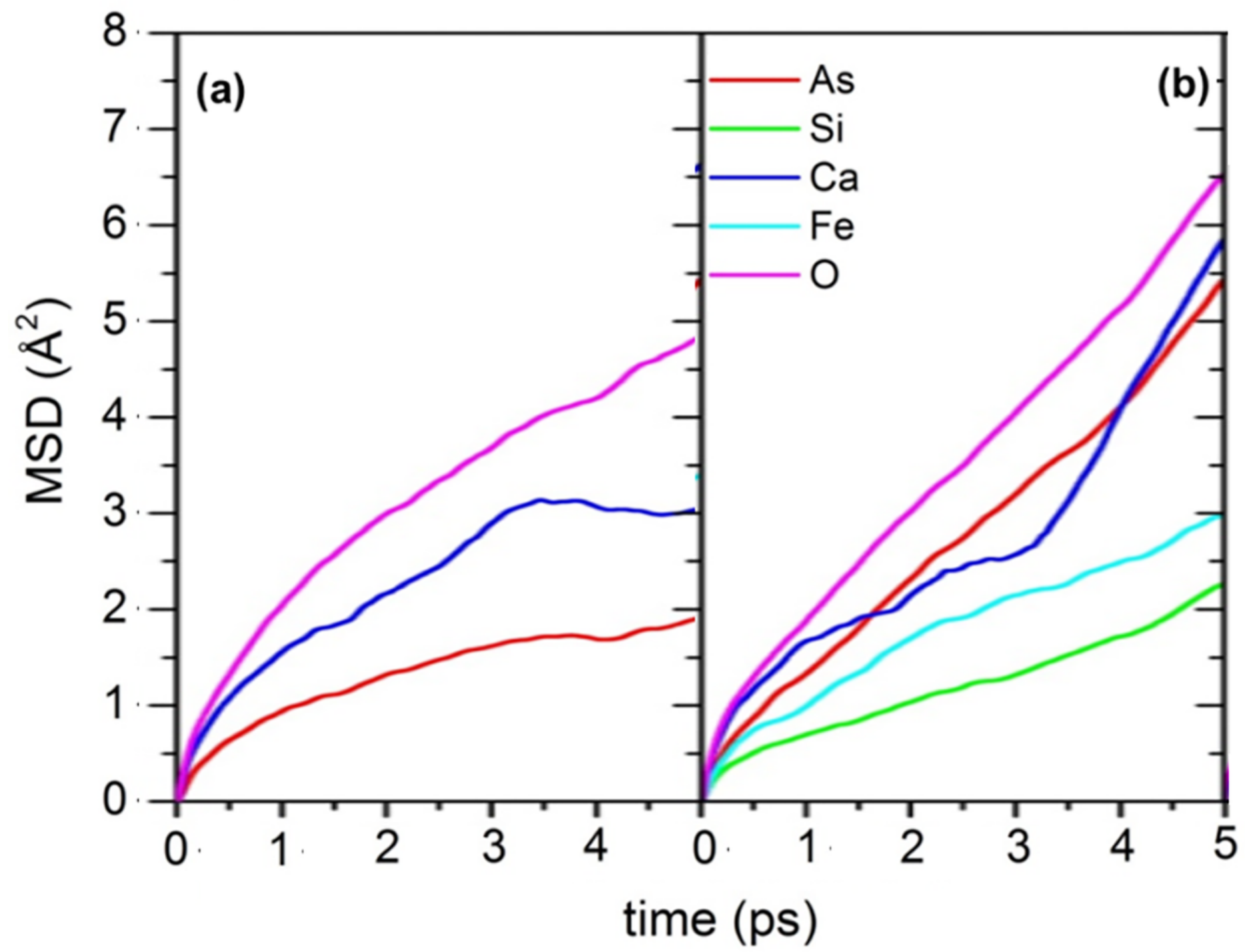

Figure 11

Mean square displacement of different atoms in (a) CaHASO4 and (b) (Ca0.5Fe0.5)H(As0.5Si0.5)O4. 


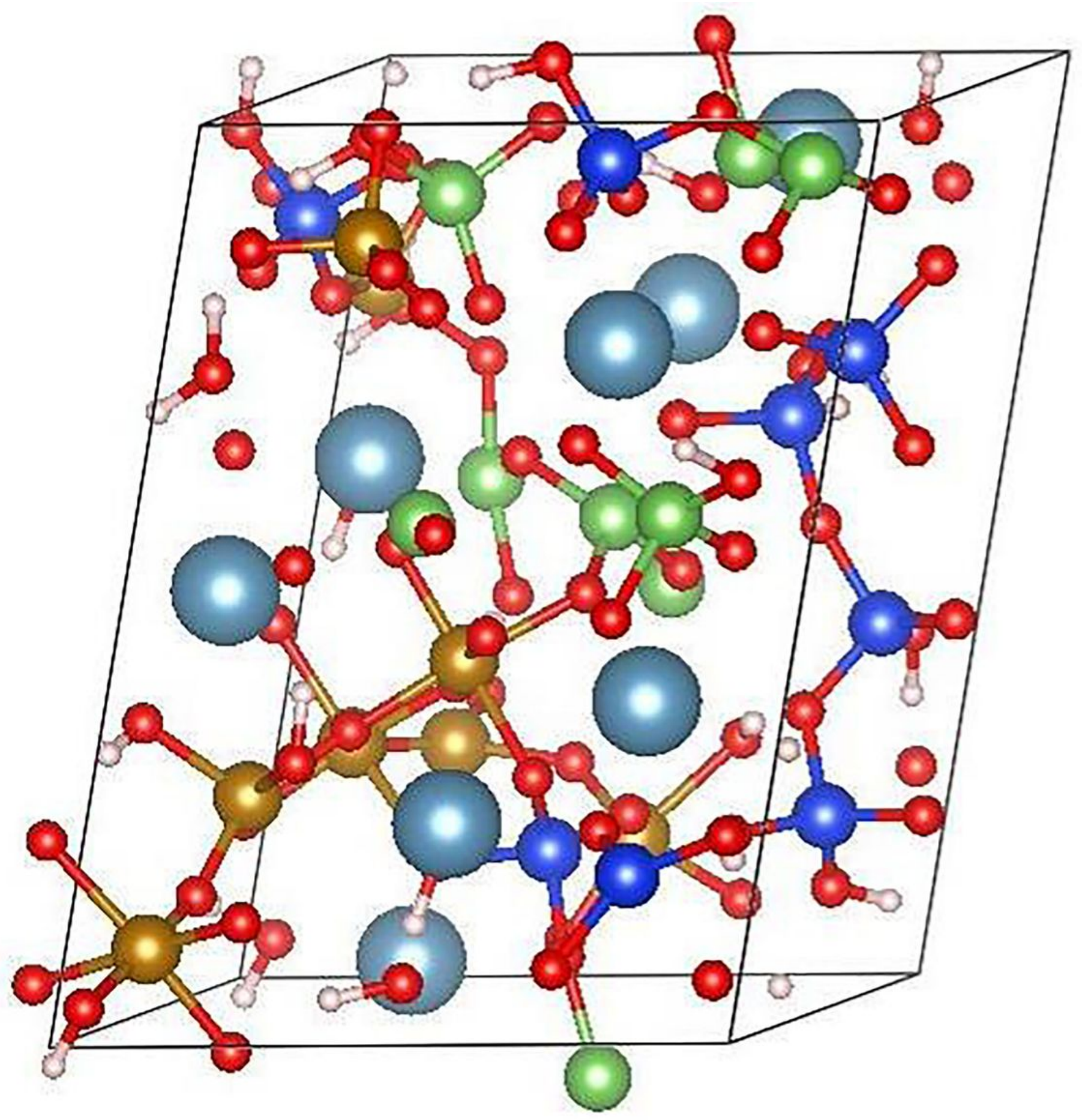

Figure 12

The simulated structure of $(\mathrm{Ca0.5Fe0.5)} \mathrm{H}(\mathrm{As} 0.5 \mathrm{Si0} .5) \mathrm{O} 4$ after sintering (red, green, blue, gray, brown and white spheres represent $\mathrm{O}, \mathrm{As}, \mathrm{Si}, \mathrm{Ca}, \mathrm{Fe}$ and $\mathrm{H}$ atoms, respectively) 